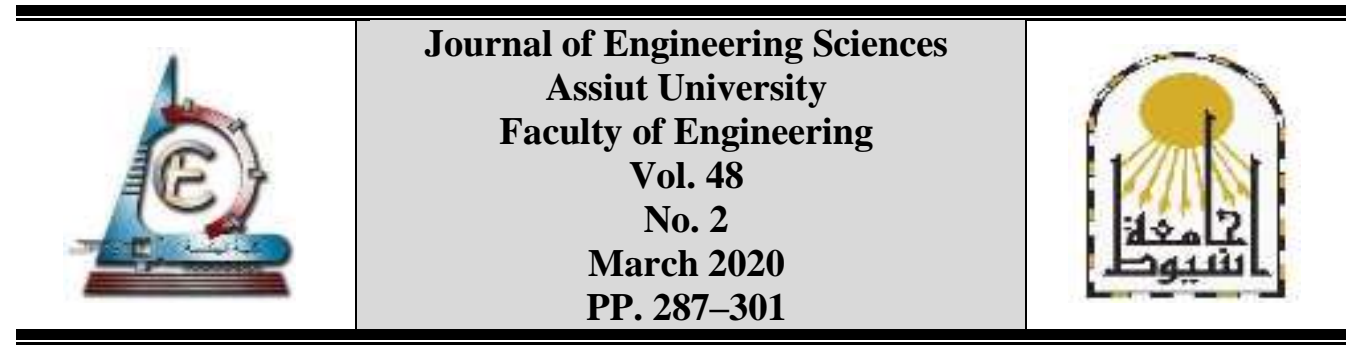

\title{
XERISCAPE AS AN APPROACH TO SAVE WATER IN LANDSCAPE PROJECTS
}

\author{
Dalia Wagih A.AlHalim
}

\author{
Architectural Department- Faculty of Engineering at Mataria - Helwan University \\ Email address: daliawagih_arch@yahoo.com
}

Received 29 June 2019; Accepted 16 September 2020

\begin{abstract}
Water is an important rare resource that needs to be saved. In spite of considering landscape architecture as one of the most components of cities that use a huge amount of water, it can be an approach to save water without losing the beauty of cities. Therefore, the research pinpoints the dilemma of landscape architecture and its relationship with water and how to design the landscape using less water by different means. The research argues that xeriscape concept is an approach to guarantee the sustainability of landscape architecture. This can be achieved by the ideal usage of water by selecting the suitable techniques either the irrigation system or reusing water, moreover, by the proper management for landscape architecture and its requirements. The research discusses these approaches through the literature review and concludes the different means of saving water by applying the xeriscape concept, irrigation systems, and management. These means are summarized in a schedule in order to be a guide for landscapers to save water in landscape architectural projects. This schedule is used to measure the percentage of applying the concluded items for saving water in different selected gardens to illustrate some useful water-conserving techniques in landscape architecture.
\end{abstract}

Keywords: Xeriscape; Saving Water; Landscape architecture; Irrigation; Reuse Water.

\section{Introduction}

Landscape as one of the main features in cities is considered the most important use that demands huge amount of water which need to be reduced and at the same time to save water without losing the beauty of cities. There are many concepts that can be established to save water in landscape design to guarantee its sustainability. The most famous concept is xeriscape that can be held through applying its main principles to save water especially in arid zones. The research pinpoints, in its theoretical study, the xeriscape concept that can be reinforced by the suitable selection for either the irrigation systems that are helpful tools in saving water, or reusing water whether rain or grey water not only to fulfill the needs of irrigation but also to save fresh water. Finally, the research discusses the management as the main tool that lead to sustainable landscape by using successful programs to manage both plants and water usage. At the end, the research presents some selected public and private projects to discuss their approach for saving water by different means. 


\section{Methodology}

In order to discuss the main argument of this research and to achieve its objectives, the methodology of this paper relies on developing a theoretical foundation by presenting the most famous concept in saving water and the management for maintenance. The research depends on the hypothesis of reaching to the sustainable landscape architecture by applying xeriscape concept with selecting the suitable irrigation system through a wise management program. The research depends on the methodology of water-wise landscaping concept that was known to offer saving both water and money that guarantees a sustainable landscape architecture. This can be achieved by lessening the irrigation cost, maintenance, and offers new ways to provide landscape regarding its beauty [1

\section{Xeriscape concept}

Xeriscape was known in 1981 as a combination between two words: landscape and the Greek word "xeros" meaning dry [1]. Xeriscape means dry but not dull, it started as a principle to save water then became a landscape style especially in arid zones. The main goal is to save water that can be achieved by using native plants such as desert plants, and natural hard elements such as rocks. Plants have to be selected in a wise way to provide the needed design regarding varieties in shapes and colors and at the same time save water. Moreover, by the usage of hard elements the landscaper can create large areas for rest and gathering of people such as patios that must be manipulated to serve the design and minimize the planted areas [2].

Xeriscape is based on seven principles that can be summarized in the following [1] [3]:

- Design and Planning: plants can be classified to minimal need for irrigation (natural rainfall), moderate needs for irrigation (occasional watering), and highly needs for irrigation (regular watering). To minimize the usage of irrigation, the designer has to maximize the usage of little irrigation plants and minimize the highly irrigation ones. Moreover, plants must be spatially distributed in hydrogroups. Each group consists of plants that have similar needs of irrigation. Also, the designer has to use more shaded areas to prevent the highly loss of water that can be resulted from the radiation of heat caused by hard surfaces.

- Minimizing turfs: turfs are considered one of the main elements in the landscape but they need to be regularly watered to keep green. Therefore to save water, the designer has to minimize using turfs. Moreover, in great demand for its usage, the types of turfs must be selected to depend on rainfall more than watering.

- Selecting plants: the designer has to select the suitable types of plants considering both site and climate. The most desirable types are those that have the ability to save water for a long interval. It is preferable to select native plants that have to be grouped in areas to facilitate its irrigation and maintenance.

- Soil analysis; the soil must be analyzed to find out its contents and if it needs to be improved to fulfill both the needs of plants and require less irrigation. If the soil needs fertilizers, it is preferred to use organic materials than the artificial ones, as the later need more irrigation than the natural ones.

- Mulching: mulches decrease the evaporation from the soil and help it to keep water. Using mulches whether organic, such as wood chips, or inorganic, such as limestone, can conserve soil moisture, control erosion and reduce weeds. The best type is the organic mulches as the inorganic ones can cause heat radiation that in turn increases the need of plants to water. 
- Efficient irrigation: healthy landscape can be created by effective irrigation. This efficiency can be achieved by dividing the types of plants into groups according to their needs of water, irrigating grasses separately from shrubs and trees, finding an efficient system for irrigation such as drips or sprinkler systems, adding some aiding materials such as fertilizers and mulches, maximizing the shaded areas, selecting the suitable time for irrigation to decrease the evaporation of water, selecting the suitable way of irrigation such as watering only in need of plants and deeply to encourage the growth of roots.

- Providing suitable maintenance: a suitable way of maintenance must be selected for different areas and different types of plants such as:

$\circ$ Mowing grass at the proper height to conserve water by encouraging it to grow healthier and deeper.

- Applying fertilizers with a suitable amount, types and at an appropriate time can save effort, money and time. The designer has to avoid using fertilizers in drought times as it encourages the demand of water.

o Finding a schedule list for steps of maintenance: fertilizing, watering, checking the health of plants, curing their diseases periodically, the needed workers for each task, the intervals of maintenance, and the tools that are needed for each interval. The schedule has to be connected to a computerized system to facilitate maintenance.

\section{Irrigation systems}

There are many systems in irrigation, manual and automatic systems. Nowadays, the usage of automatic systems became the main goal in irrigation to save water.

\subsection{Hand irrigation system}

Hand watering can address the need of plants and soil; as one can control both time and amount of water from the observation of the case of plants. Hand watering must take place through using a hose with a nozzle that delivers water in a spray to be distributed to the soil. In case there is no nozzle, the hose delivers a huge amount of water and results in the soil run off that means a great loss in water. The plant has to be watered once and left for about 15 minutes before another dose of water to permit the fully soaking of the soil to water [4].

\subsection{Automatic irrigation systems}

In spite of their efficiency, not all automatic systems save water. It depends on the design of the system and its compatibility with the types of plants and their needs for water in different seasons. The automatic system depends on a selected device for watering that is connected to a designed program which controls the intervals of watering. The automatic system must be checked and its components must be maintained at interval times. Selecting the suitable device for irrigation must regard many considerations such as the type and porosity of the soil, the amount of water, the available water in the site for irrigation, and the needs of the plants. Some of the irrigation devices are [4] [5]:

- Bubblers: they are small plastic head emitters with a threaded joint. They provide water in the form of the fountain above the ground level, they are suitable for irrigating trees, as each tree has its bubblers due to its needs of water.

- Drip Irrigation: it is suitable for small yards or special selected plants. By drip irrigation, the garden can be watered in one hour by one to four gallons directly to the soil, the evaporation can be lessened due to a large amount of water at the same time; moreover, there is no need to remove mulches before irrigation as the water is directly soaked into the soil. 
- Sprinklers: they are suitable for large areas. Sprinklers can be automatized by programming the system to irrigate plants in both selected intervals and amount of water; it can also be used manually in watering gardens but in this case, one must open the valve by himself and control the amount of water.

\subsection{Selecting irrigation systems}

If the irrigation system is not designed to be efficient, it causes loss of water and affects plants negatively, some of these problems can be summarized in [6]:

- Over watering causes the disease of plant, rotten roots due to extra water, loss of both water and money.

- The failure to measure the adequate amount of water to every type of plant in different seasons.

-Watering at undesirable time of the day results in water wastage due to evaporation.

- Fixing the system of irrigation to different types and sizes of plants affects new plants which need more water than the existed ones.

- The failure to maintain the different components of the system affects its efficiency and results in inadequate irrigation to plants.

To establish an adequate irrigation system that guarantees the sustainability of the landscape by saving water, some recommendations must take place [4] [6]:

- Select the suitable system due to the type of plants; lawns need for watering differs than the needs of shrubs and trees.

- Manage between the needed amount of water and the selected irrigation system with its ability to provide water.

- Water the lawn in case it shows signs of drought only.

- Water shrubs and trees in the drip line (the area under the shade of the tree or shrub), which is the area of the spread roots.

- Water the new plants separately from the existed ones.

- Water as less as possible but deeply to reach the roots of plants.

- Water regarding the quantity of water more than the units of time.

- Water due to the type of soil.

- Water plants each time not more than one inch that allows soaking of water to about 10 inches deeply in the soil.

- Use only $1 / 4$ inch of water for the purpose of activating granular fertilizer.

- Water between midnight and sunrise as in this interval the evaporation of water from the soil is the minimum.

- Establish an automatic shut-off system that stops watering during raining.

- Separate plants in different areas due to their need of water.

By establishing a suitable irrigation system regarding the needs of plants and watering in need only, lead to save both water and money.

\section{Reuse water}

Water as a precious resource and irrigation uses huge amounts of it every year. Therefore, water has to be used multiple times whenever possible. There are two ways to benefit from water by using rainwater and waste water. 


\subsection{Rain harvesting}

It is an ancient system that depends on collecting rain-water and use it in irrigation, this system can save a large amount of water. It can be simply done using gutters on the roofs of buildings to gather water that can be transported through pipes to tanks in which water can be stored for drought time, and to decrease the amount of using fresh water in irrigation. Then water can be transported to the irrigation system using pumps after filtering it from any undesirable materials using filters [2] [7]. To install rain harvesting system, there are some considerations to be regarded, some of which are [7]:

- Selecting the irrigation system: manual irrigation is suitable for little amount of rainwater, but automatic irrigation needs a huge amount of water.

- Designing the roof of the building: metal smooth roofs are more suitable for catching rain water than other surfaces. Avoiding the dense plantation of roofs as plants with its components such as leaves can prevent the flow of water on roofs through gutters by clogging them.

- Designing the components of the system: tanks must have lids to avoid the spread of insects and to keep the water cleaned after filtration. Pipes have to be vertical to use gravity as possible rather than pump to save energy.

- Maintenance: keep the components of the system clear from any undesirable materials, clean filters regularly, trim the stems and leaves of trees that are close to the building to protect the roof from leaves and wastes that can be resulted from birds and their nests, check the tanks and the system of irrigation regularly to keep their efficiency.

\subsection{Waste water}

Wastewater and its reuse for irrigation is another way in saving water, this concept is an old one that was used by the ancient Greeks. Reusing wastewater has many benefits; it conserves water, reduces environmental effects, enhances the production of food, and minimizes using the artificial fertilizers because of the nutrients contained in the wastewater. Not all the wastewater can be reused in irrigation; as raw wastewater that are resulted from toilet flushing and construction activities, are rejected for irrigation but they can be treated and used in other fields such as industrial purposes, the other wastewater such as those resulted from sinks can be treated and reused in irrigation. Treated wastewater can be divided into two levels of treatment; high level for irrigating plants that produce food like fruits and vegetables, and less treatment for non-productive plants such as decorative trees [8] [9].

Reusing greywater is expensive for existing building, it can be designed for a new building as it needs a dual system for plumbing through which water from sinks and tubs can be gathered, three-way valve to divert extra water to special system, treatment system to treat water then store it in tanks to be used in need, and pumps to deliver stored water to the irrigation system or to toilets flushers [9].

There are some restrictions in using greywater in irrigation some of which are [7]:

- Never irrigate plants that provide food (vegetables, fruits or grains) with greywater even after treatment.

- Don't use greywater that contains chemicals for its harmful effect on plants.

- Maintain the system regularly by cleaning its components.

- Provide tanks for storage with lids or covers to prevent the spread of insects. 
- Keep noses and eyes far enough from the tanks and water.

- Don't use greywater in houses if any member of the family has a history in infectious disease.

\section{Managing plants and irrigation}

Management is an effective approach in saving water; starting from the designing stage ending by the maintenance stage [10] [11]:

- Design stage: designers have to analyze the site through the location, climate (temperature, humidity, wind directions, and speed), and the efficient system for irrigation, etc. the designer has to:

o Select suitable types of plants that need less water regarding the considerations of both the site and plants; as the selection of the most drought and heat tolerant plants for the areas that are exposed to sun, and the most shade tolerant for shaded areas.

o Decrease the usage of turfs and lawns to be used only in need where it provides desired function such as recreational activities.

- Group the types of plants with the same requirements in the same areas to facilitate the irrigation with a suitable amount of water.

o Use organic mulches that is more useful for plants and less need for usage of water rather than the artificial mulches.

- Construction stage: the soil must be examined and prepared to be suitable for the selected types of plants including adding fertilizers.

- Operation \& Maintenance stage: in this stage, there are some considerations that can be summarized in the following:

o The irrigation must depend on rainfall first then can be completed by the installed irrigation system with establishing watering only in need of plants. The irrigation must be deeply especially after drought or hot times, moreover, the time of watering must be selected carefully to decrease the evaporation of water; as in the early morning, the heat and wind are the lowest.

o The irrigation systems must be fixed and repaired regularly to ensure the proper flow of water.

- Minimize the usage of fertilization with careful selection of its types due to different times and avoid its usage in drought ones as it increases the demand of plants towards the water.

- Regular mowing to help the plants to grow deeply that increases the absorption of plants to water from the ground, thus less need for watering.

o Regular trimming for broken or disease parts of plants to permit the penetration of sunlight to the lower parts of the plants that help it in completing the photosynthesis process.

o Sharpening the plants in the pruning process to prevent the loss of water from plants and avoid disease.

\section{Summation for the theoretical study}

As mentioned previously in the first part of the study, I assume that the designer has to put in consideration the concept of saving water from the first step of design regarding the needs of plants without sacrificing design aesthetics. To achieve this, the research 
concludes the main items that must be achieved in designing landscape architecture as shown in table (1). (If each item takes one point then the total items take 14 points).

Firstly, the designer has to select the concept of designing regarding the goal of saving water by establishing the concept of xeriscape with its principles from the first step of design by analyzing the soil, selecting the suitable types of plants that save water, minimizing the turfs that use huge amount of water, selecting an efficient type for irrigation, ending by the stage of maintenance that must be planned to produce successful gardens by minimum budget and minimum water usage.

Secondly, the designer has to select the irrigation system that suits the design, whether hand irrigation or automatic irrigation system. The designer has to select the system that saves more water and fulfills the needs of plants and he/she has to calculate the amount of water needed per day, per week, and per month. These calculations can guide the designer to the suitable system that fulfills the requirements of plants regarding the weather of each season all over the year.

Table 1.

Means of saving water in landscape architecture

\begin{tabular}{|l|l|}
\hline \multicolumn{1}{|c|}{ Means of saving } & \multicolumn{1}{|c|}{ Items of saving } \\
\hline \multirow{4}{*}{ Xeniscape } & Design \& Planning \\
\cline { 2 - 2 } & Minimizing Turfs \\
\cline { 2 - 2 } & Selecting Plants \\
\cline { 2 - 2 } & Soil analysis \\
\cline { 2 - 2 } & Mulching \\
\cline { 2 - 2 } & Efficient ingation \\
\cline { 2 - 2 } & Suitable maintenance \\
\hline Irigation System & Hand irigation \\
\cline { 2 - 2 } & Automatic ingation \\
\hline Reuse Water & Rain water \\
\cline { 2 - 2 } & Waste water \\
\hline Managing Plants \& Irrigation & Design stage \\
\cline { 2 - 2 } & Construction stage \\
\cline { 2 - 2 } & Operation \& Maintenance stage \\
\hline Total points= & 14 points \\
\hline
\end{tabular}

Thirdly, the designer has to find out the source of water whether fresh or reused water. It is preferable to reuse water especially for non-productive plants. The designer has to manage the system of inputting water regarding safety and healthy levels. Moreover, the designer has to supervise the suitable flow of water through the selected system in order to save water, effort and fulfill the needs of plants.

Finally, the designer has to establish a complete program for maintenance and irrigation in the form of designed schedules for all the components of the stage regarding labors, tools, intervals, types of plants, ... etc. this can be managed using a computerized system.

Each item of the previous items takes (one) point in case of existing. Therefore, the total points for the whole items equal (14) points. This was done to calculate the percentage of applying these items through the selected gardens in the analytical study.

\section{Analytical study}

\subsection{Experiences of cities in saving water}

Many projects were held to save water all over the world. The research produces two experiences in saving water in Mesa, Arizona, and Taos, Mexico. 
- Mesa, Arizona: in 2002 a management team succeeded to save $15 \%$ of water over the year representing savings of more than $\$ 400,000$. The team took many steps to save water that can be summarized in [12]:

○ Minimizing the numbers of over seeded areas.

$\circ$ Testing the automatic runoff shut devices that are used for watering in seven parks to fix it.

o Reducing the hours of operating fountains.

O Encouraging native plants and desert landscape all over the city.

○ Publishing the idea of xeriscape and encouraging citizens to use it.

○ Educating residents many ways that can be used to save water in their gardens.

- Taos, New Mexico: is over populated that needed to save energy and water with providing the different requirements of city and citizens. In 2009, the council of the city began their project of saving water through the participation of volunteers with the town officials and hired consultants to save energy in new and old buildings of the city. The council formed a committee from its members, volunteered citizens, landscapers, planners, and experts. The committee took many decisions by establishing some regulations after publishing them to residents. These regulations guide people in building their new buildings and in renewing their old ones to preserve energy especially water economically by different means. Xeriscape was the main concept to save water with the usage of grey water in the automatic selected irrigation system, such as drips irrigation. The committee found that the most effective approach to citizens is the bills of water, so it published the idea of decreasing the bills if the citizen decreases the usage of fresh water. Also, the idea of refunds was established; so that the family can gain refunds for different fields due to their percentage of achievement in saving water [13]. These ideas succeeded to lessen the usage of fresh water.

From the previous two experiences, it is obvious that each project used the xeriscape principles in saving water to guarantee sustainable landscape architecture. The approach of saving money was important to encourage people to save water. The cooperation between citizens, volunteers, experts and local authorities took place to reach to the main goal of saving water. It can be concluded that xeriscape, irrigation, reusing water and good management lead the main target in saving water that can be fulfilled to save both money and energy.

\subsection{Experiences of small private gardens}

Saving water became a trend for people in their gardens; as this trend results in conserving a precious source (water) and saving money by decreasing the water bill. In the following the research presents some selected private gardens in both Colorado-U.S.A. and New Cairo-Egypt.

\subsubsection{Private Gardens in Colorado-U.S.A}

A drought took place in Colorado from 2002-2004, this drought resulted in the feeling of citizens of the great value of water, so xeriscape became the main concept in designing gardens that saved about $48 \%$ of the water in the irrigation needed for landscape architecture [14]. Using native plants or plants that need less water, also maximizing the usage of hard elements especially the natural ones such as rocks, resulted in saving water [15]. The following are some examples of selected gardens which use xeriscape in designing a beautiful garden that saves water. 
- Garden 1: a private garden that was redesigned in Boulder, Colorado by the designer Alison Peck [16]: It is a rock gardening style, in which the designer uses drought-tolerant plants and hard elements instead of other elements that needed a large amount of water. The garden needed less maintenance and irrigation through the usage of an automatic drip irrigation system. The designer used native grasses that need less watering and selected many colorful flowers that were designed in a picturesque style; rosy, blue and pink flowers together, magenta and white flowers together. She arranged plants with hard elements as the following:

○ A sculpture rock garden at the front that replaced a thirsty bluegrasses lawn, and another rock garden at the backyard of the house.

o Stones with angular sharp face with colored rosy, blue and pink flowers in pots among these stones.

○ A frame of red stones patio where she planted many colored flowers that are exposed to sun and wind.

- Garden 2: Mary Ellen Keskimaki's garden in Golden Colorado that appeared colorful in the four seasons [17]. Irrigation was decreased to be each two weeks in summer, then in autumn the falling leaves are used as mulches to cover the soil and prevent the water evaporation till the end of winter, then in spring these leaves are removed. To keep the garden colorful in the four seasons, the designer selected plants that cover the soil completely, native grasses that need less water, arranging the colorful plants to look different each season:

o In summer, purple flowers appear around old tall bearded irises.

o In autumn, a strong contrast in colors appears by the growth of green silver mats and pink plants.

- In winter, the green carpets of fine textured grasses grow and stay green all the season with the glossy leaves of other plants.

○ In spring, grow small flowers among the groundcovers followed by other blue flowers. Also, Orange, yellow and red tulips grow to display a pictured scene to the garden.

The previous two gardens showed that the designer can use various types of landscape elements to fulfill his/her target in designing with saving water without losing the beauty of the garden. Each garden applied about $64.3 \%$ from the proposed means of saving water that were concluded from the theoretical study of the research (table 2). 


\section{Table 2.}

Means of saving water in private gardens in Colorado

\begin{tabular}{|c|c|c|c|c|c|}
\hline $\begin{array}{c}\text { Means of } \\
\text { saring }\end{array}$ & Items of savinz & \multicolumn{2}{|l|}{ Garden 1} & \multicolumn{2}{|l|}{ Garden 2} \\
\hline \multirow[t]{7}{*}{ Xerweape } & Detiger \& Planning & Rock style & & Celorful in 4 seatons & \\
\hline & Minimming Terf & Native ganes & & Native gratses & \\
\hline & Selecting Plants & Nasive plants & & Native plants & \\
\hline & Sot analyzs & Anatyzed & & Analyzed & \\
\hline & Mulclung & No data & $\square$ & Usung mulches & \\
\hline & Etheient imgation & Eftreient & E & Effrient & \\
\hline & Suitable maintenance & Less maintenance & & Less maintenance & \\
\hline \multirow{2}{*}{$\begin{array}{l}\text { Imipation } \\
\text { System }\end{array}$} & Fiand ingigation & Not used & $\square$ & Nodata & $\square$ \\
\hline & Autormatis imigation & Drip Irrigatien & L & No data & $\square$ \\
\hline \multirow{2}{*}{$\begin{array}{l}\text { Reusen } \\
\text { Water }\end{array}$} & Rain water & No data & $\square$ & No data & $\square$ \\
\hline & Waste watet & No data & $\square$ & No data & $\square$ \\
\hline \multirow{3}{*}{$\begin{array}{l}\text { Manageng } \\
\text { Plarks \& } \\
\text { Imigation }\end{array}$} & Deriga stage & $\begin{array}{l}\text { Native Plants } \\
\text { Saocks }\end{array}$ & & Native coloriful plants & \\
\hline & Construction stage & No data & $\square$ & No data & $\square$ \\
\hline & $\begin{array}{l}\text { Qperation } \alpha \\
\text { Mainkenance stage }\end{array}$ & Less maintenance & 口 & Less maintenance & \\
\hline \multicolumn{2}{|c|}{ Total Points" } & & 9 & & 9 \\
\hline \multicolumn{2}{|l|}{ Percentage"- } & & 64.35 & & $643 \%$ \\
\hline
\end{tabular}

Existr-1 NotExint0

\subsubsection{Private Gardens in New Cairo-Egypt}

New Cairo in Egypt includes large areas for open spaces that need a huge amount of water which need to be reduced to save water and money to guarantee a sustainable landscape architecture. The research selected two gardens for private villas in both ElRehab and Madinaty cities with approximately equal areas.

- A private villa in El-Rehab City. The villa included a small garden $45 \mathrm{~m} 2$ as shown in figure $(1,2)$. The system of watering is a mix between automatic and hand watering systems; 4 sprinklers for 15 minutes daily besides using a manual hose. The designer used native plants in his design, ground covers, shrubs, climbers and trees. The trees are planted around the garden that is covered with grasses. The designer selected some shrubs around the garden and in some selected areas inside it to form decorated areas. The area of plants is decreased using rocks and stones in decoration, gravel tiles for paths, besides an area of about $8.7 \mathrm{~m} 2$ that is used as a rest area.

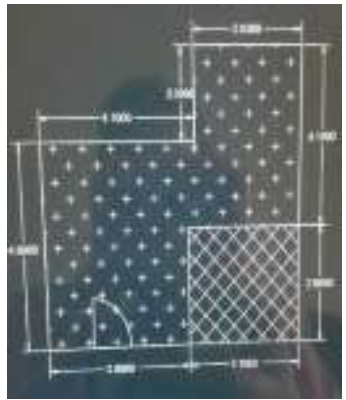

Fig. 1. Plan of the garden

From the previous presentation of the garden, the research concludes many positive and negative points that can be summarized in: 
- Positive points in applying some of the concepts of xeriscape in which the designer used native plants and rocks in design, native grasses in turfs and decreased its area by using rocks in paths and a rest area of about $8.7 \mathrm{~m} 2$ that is designed using durable materials such as rocks and wood that need less maintenance. The designer selected native trees, shrubs and grasses. There is a combination between hand irrigation and automatic one to fulfill the different needs of different plants.

- Negative points in neglecting some concepts of saving water that appeared in using turfs which need a huge amount of water, collecting different types of plants that need a different amount of water in the same group, not using mulches to prevent the evaporation of water from the ground, and the absence of using reused water.

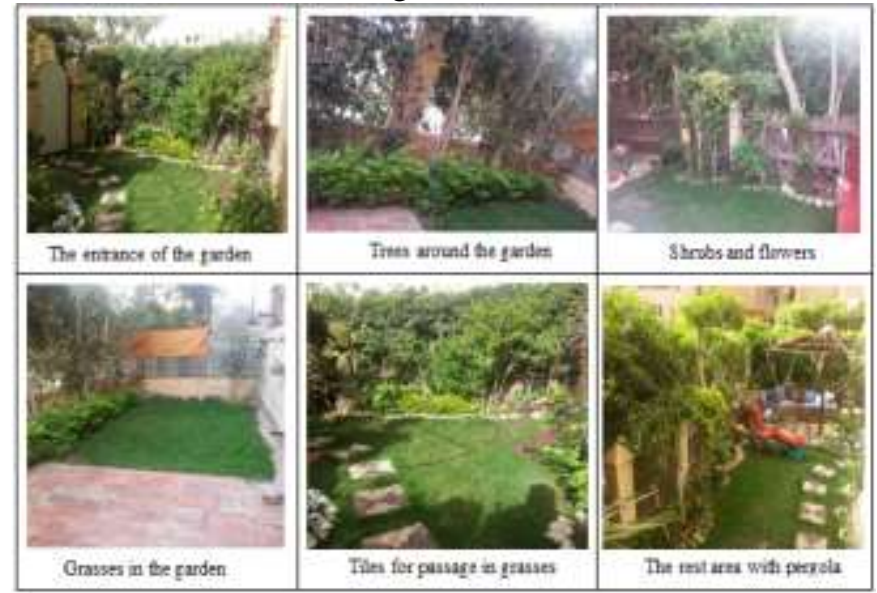

Fig. 2. The used elements of landscape in the garden of the villa

According to the electronic water meter of the villa, it was found that the garden uses $1.6 \mathrm{~m} 3$ of water daily (this was calculated by closing all the valves of water pipes to the villa except for the garden, then finding out the amount of water consumption to irrigate the green area). The plants need watering twice daily in summer and once daily in winter.

\section{Total amount of water needed/ day in summer $=1.6 \times 2=3.2 \mathrm{~m} 3 /$ day}

Total amount of water needed/ day in winter $=1.6 \mathrm{m3} /$ day

Then total amount of water each year $=(30 \times 6 \times 3.2)+(30 \times 6 \times 1.6)=864 \mathrm{~m} 3 /$ year

According to the last water bill in 2019 , the price of $1 \mathrm{~m} 3$ of water $=2.8 \mathrm{~L} . \mathrm{E}$.

Then the total cost of irrigation $=864 X 2.8=2419.2$ L.E./year

If the xeriscape can be applied completely, according to Colorado's case, the amount of water can be reduced to $48 \%$ so the cost will be reduced also by the same percentage:

Total amount of water after using xeriscape $=864-(864 X 48 \%)=449.28 \mathrm{m3} /$ year Total amount of saving money after using xeriscape $=449.28 X 2.8=1257.98$ L.E./year

That is means decreasing the cost of money $=2419.2-1257.98=1161.22$ L.E./year

- A private villa in Madinaty City, El Golf- New Cairo. The area of the garden $37.5 \mathrm{~m} 2$ as shown in figure $(3,4)$. The system of watering is automatic of about 15 minutes daily for both sprinklers and bubblers; 10 sprinklers ( 3 sprinklers for the backyard, 5 sprinklers for the side garden and 2 sprinklers for the front garden) and bubblers around the trees, each group of sprinklers has a separate valve. The designer used native plants in his design, ground covers, shrubs, and trees. The trees and shrubs are planted around the garden that is covered with grasses. Tiles 
of ceramic, wood, stones, and bricks cover a pedestrian path around the villa, the entrance of the villa, and a space for parking one car [18]. The total area of the green area is about $21.8 \mathrm{~m} 2$, and the total area of hardscape is about $15.7 \mathrm{~m} 2$.

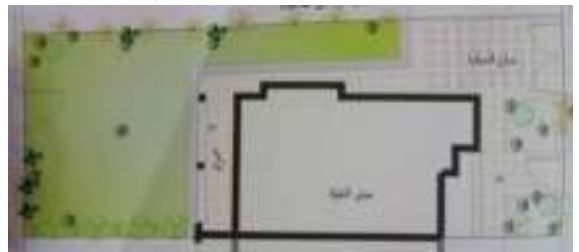

Fig. 3. Plan of the garden and the villa [18]

From the previous presentation of the garden, the research concludes many positive and negative points that can be summarized in:

- Positive points in applying some of the concepts of xeriscape in which the designer used native plants and hard elements in design, native grasses in turfs and decreased its area by using durable natural tiles, rocks, wood and bricks in paths that need less maintenance. The designer selected native trees, shrubs and grasses after analyzing the soil. The designer used automatic irrigation using sprinklers for watering grasses and bubblers for irrigating trees and shrubs.

- Negative points in quitting some of the concepts of saving water that can be appeared in using turfs that need huge amount of water, planting different types of plants in groups that need different amount of water, not using mulches to prevent the evaporation of water from the ground, and the absence of using reused water that can save huge amount of water.

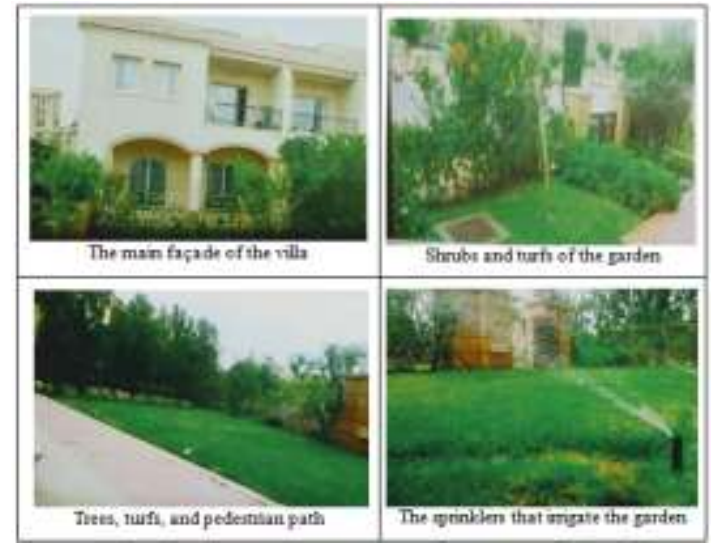

Fig. 4. The used elements of landscape in the garden of the villa [18]

According to the electronic water meter of the villa, it was found that the garden uses 1.125 $\mathrm{m} 3$ of water daily (this was calculated by closing all the valves of water pipes to the villa except for the garden, then finding out the amount of water consumption to irrigate the green area). The plants need watering twice daily in summer and once daily in winter that is meaning [18]:

\section{Total amount of water needed/ day in summer $=1.125 \times 2=2.25 \mathrm{m3} /$ day}

Total amount of water needed/ day in winter $=1.125 \mathrm{~m} 3 /$ day

Then total amount of water each year $=(30 X 6 \times 2.25)+(30 X 6 \times 1.125)=607.5 \mathrm{~m} 3 /$ year

According to the last water bill in 2019 , the price of $1 \mathrm{~m} 3$ of water $=2.8 \mathrm{~L}$.E.

Then the total cost of irrigation $=607.5 X 2.8=1701$ L.E./year 
If the xeriscape can be applied completely, the amount of water can be reduced to $48 \%$ that is to say the cost will be reduced also by the same percentage, which means:

Total amount of water after using xeriscape $=607.5-(607.5 X 48 \%)=315.9 \mathrm{~m} 3 /$ year

Then the total cost of irrigation after using xeriscape $=315.9 X 2.8=884.52 \mathrm{~L} . \mathrm{E}$.

That is means decreasing the cost of money=1701-884.52=816.48 L.E./year

The previous two gardens in New-Cairo showed that the designer can save both water and money by applying the means of xeriscape, irrigation and management concepts that were concluded from the theoretical study. El-Rehab garden applied about $71.4 \%$, while Madinaty garden applied about $64.3 \%$ from the means of saving water (table 3 ).

The researcher Sobhi [18] due to his study for the private garden in Madinaty, suggested another two scenarios for designing the garden. He calculated the total amount of water needed for irrigation/ $\mathrm{m} 3$ by closing all the valves of water in the villa except those which are needed for the garden. By observing the total amount of used water for irrigation/minute, as was read from the electronic water meter, he could find out the total amount of water needed for each scenario. The first scenario was decreasing natural turfs and replacing it by an artificial one. By applying this suggestion, the usage of water can be lessened to $70 \%$ from the current situation. The second scenario was reusing waste water in the villa. By applying this suggestion, the usage of fresh water can reach to $0 \%$. But this need to establish a complete reusing system that can cover its cost, due to Sobhi's study and calculations, in 7 years only [18].

By applying the concept of xeriscape, irrigation, and management all over the landscape architectural projects in New-Cairo, a huge amount of water can be saved, which will be more economic.

Table 3.

Means of saving water in private gardens in New-Cairo

\begin{tabular}{|c|c|c|c|c|c|}
\hline \begin{tabular}{|c|}
$\begin{array}{c}\text { Means of } \\
\text { saving }\end{array}$ \\
Xeriscape
\end{tabular} & \multirow{2}{*}{$\begin{array}{l}\text { Items of saving } \\
\text { Design \& Planning }\end{array}$} & \multicolumn{2}{|c|}{ El-Rehab Garden } & \multicolumn{2}{|l|}{ Madinaty Garden } \\
\hline & & $\begin{array}{l}\text { Native plants \& } \\
\text { rocks }\end{array}$ & $\square$ & $\begin{array}{l}\text { Native plants, } \\
\text { Ceramic tiles, wood, } \\
\text { stones, and bricks }\end{array}$ & \\
\hline & Minimizing Turfs & Native grasses & $\square$ & Native grasses & E \\
\hline & Selecting Plants & Native plants & $\square$ & Native plants & E \\
\hline & Soil analysis & Analyzed & $\square$ & Analyzed & E \\
\hline & Mulching & Not used & $\square$ & Not used & प \\
\hline & Efficient irrigation & Efficient & $\square$ & Efficient & $\square$ \\
\hline & Suitable maintenance & Less maintenance & $\square$ & Less maintenance & $\square$ \\
\hline \multirow{2}{*}{$\begin{array}{l}\text { Irrigation } \\
\text { System }\end{array}$} & Hand irrigation & Manual hose & $\square$ & Not used & $\square$ \\
\hline & Automatic irrigation & Sprinklers & $\square$ & $\begin{array}{l}\text { Sprinklers } \\
\text { Bubblers }\end{array}$ & $\square$ \\
\hline \multirow{2}{*}{$\begin{array}{l}\text { Reuse } \\
\text { Water }\end{array}$} & Rain water & Not used & $\square$ & Not used & $\square$ \\
\hline & Waste water & Not used & $\square$ & Not used & प \\
\hline \multirow{3}{*}{$\begin{array}{l}\text { Managing } \\
\text { Plants \& } \\
\text { Irrigation }\end{array}$} & Design stage & $\begin{array}{l}\text { Native plants } \\
\text { \&rocks }\end{array}$ & 口 & $\begin{array}{l}\text { Plants \& Hard } \\
\text { elements }\end{array}$ & $\square$ \\
\hline & Construction stage & No data & $\square$ & No data & $\square$ \\
\hline & $\begin{array}{l}\text { Operation } \& \\
\text { Maintenance stage }\end{array}$ & Less maintenance & 口 & Less maintenance & $\square$ \\
\hline \multicolumn{2}{|c|}{ Total Points= } & & 10 & & 9 \\
\hline \multicolumn{2}{|l|}{ Percentage $=$} & & $71.4 \%$ & & $64.3 \%$ \\
\hline
\end{tabular}




\section{Summation for the analytical study}

As mentioned previously in the second part of the study, it is obvious that the concept of xeriscape is considered a main effective approach in reaching the target of saving water. Moreover, the economic approach is important to encourage people to save water either in public or private landscape architectural projects.

From the cases of Arizona and Mexico, the cooperation between the government, experts and citizens appeared as an important approach to fulfill the target of saving water through landscape architectural projects. Governments established rules and regulations, experts' educated citizens and published the importance of saving water, citizens took right steps guided by governments and experts to reach to the target, and this was reinforced by the economic approach (decreasing water bill, and refunds) that was established by the government.

In the cases of private villas in Colorado-U.S.A., the gardens did not lose their beauty in spite of maximizing the usage of the hard landscape than the soft one in designing. The designers for the gardens selected native plants that need less watering and maintenance, they used a xeriscape concept to save water and guarantee sustainable landscape architecture in their beautiful gardens.

In the Egyptian private gardens, the designers applied some principles of xeriscape and ignored others; they used native plants and natural hard elements that need less maintenance, but ignored other principles such as reusing water in irrigation. The research calculated the amount of saving both water and money based on the minimum percentage of saving water according to Colorado's cases that was $48 \%$ (the minimum percentage that the research found in saving water); in El-Rehab garden it was found that it can save about 1161.22 L.E./year, and in Madinaty Garden the amount of saving money reached to be 816.48 L.E./year. This difference refers to the different areas of green space in both villas in spite of their approximate equal total areas.

Finally, the analytical study proved that using xeriscape concept is a successful approach in saving water through landscape projects that will guarantee achieving sustainable landscape architecture without losing its beauty.

\section{Conclusion \& recommendations}

Throughout this paper, a literature review on saving water through landscape projects was reviewed. The major findings were applying the concept of xeriscape to guarantee the sustainability of the landscape. This could be reached by the wise selection for the suitable irrigation system, reusing water either raining water or grey water, and the wise management for the stage of maintenance to save both water and money.

The direct relationship between water and landscaping cost is an encouraging approach for both people and governments to save water. Therefore, the research concludes that to succeed in saving water, experts have to create intelligent programs that aim to save both water and money.

Finally, the research recommends establishing a xeriscape concept to fulfill reaching to sustainable landscape architecture by saving both water and money. This target must be the main goal from the first steps of design including adequate usage of the irrigation system untills the maintenance stage for any landscape architectural project. 
Dalia Wagih A.alhalim, Xeriscape as an approach to save water in landscape projects

\section{REFERENCES}

[1] Knopf, J. “All Dried Up: Be Water-Wise with Drought-Tolerant Landscaping (Ductape) Journal of Property Management, Institute of Real Estate Management. Vol. 68 Issue: 4 (July-August 2003) pp. 58+

[2] Acoba, E. 'Xeriscape Means Dry, not Dull' AZ Daily Star Newspaper, ProQuest LC. (January 18, 2015) pp.E09

[3] Roche, J. "Xeriscaping Means Never Having to Say You're Sorry" Landscape \& Irrigation Magazine, Bev-AL Communications, Inc. Vol. 24 Issue: 6 (June, 2000) pp.16

[4] Efficient Irrigation: watering and conserving; http://wateruseitwisely.com/100-ways-toconserve/landscape-care/principles-of-xeriscape-design/efficient-irrigation/

[5] "Chapter 13: Bubbler Irrigation of Trees", Pressurized Irrigation Techniques, www.ftpftp.fao.orgdocrepfao010a1336ea1336e13, (January 2017, 3) pp. 1-6

[6] O'Connor, G. "Sprinkler Systems in the Landscape" Landscape and Irrigation Magazine, Bev-Communications, Inc. Vol.32 Issue:2 (February 2008) pp. 16

[7] http://www.h2ouse.org/tour/rain-harvesting.cfm, 2009

[8] Faruqui, N., Biswas, A. and Bino, M. eds. "Ch.1:Islam and Water Management: Overview and Principles", Book: Water Management in Islam, United Nations University Press, New York (2001) pp.1-32

[9] "How Can Recycled Water Us?", https://www3.epa.gov/region9/water/recycling/\#benefits, (January 2017,3).

[10] Wetherbee, K. "A Downpour of Color: Lush Landscaping Doesn't Require Loads of Water. (Hearth \& Home)" Sierra Magazine, Vol.87 Issue: 3 (May-June 2002) pp. 34+

[11]Fender, D. "Turfgrass Use and Water Conservation" Landscape \& Irrigation Magazine, Bev-AL Communications, Inc. Vol. 25 Issue: 6 (June, 2001) pp. 8

[12] Turner, L. "Mesa, Ariz., Water Management Efforts Bring Savings" Nation's Cities Weekly Magazine, National League of Cities, Vol.28 Issue: 33 (August 15, 2005) pp.12

[13]Alix,H. "Building Ordinances in Taos High Performance Building Ordinance Demonstrates that the Citizens of Local Communities Can Be Powerful Assets in Achieving Sustainability" The Public Manager. Vol. 39 Issue: 1, spring 2010, pp.27+ American Society for Training \& Development, Inc. COPYRIGHT 2010 Gale Group.

[14]Lagrassa, E. and Giesbrecht, C. "Xeriscape" The Gazette (Colorado Springs, CO.) Freedom Newspapers, Inc. (June 5, 2013) pp.21

[15] Hunter, N. "Landscaping Businesses See Record Xeriscape Sales; Fire, Fears, Drought Prompt Increase" The Gazette (Colorado Springs, CO.) Freedom Newspapers, Inc. (June 5, 2013) pp.22

[16] Tatroe, M. "Colorful Low-Water Plants Thrive in These Rock Gardens" Sunset Magazine , Sunset Publishing Co. Vol. 210 Issue: 5 (May 2003) pp. 107+

[17] Tatroe, M. "Year-Round Color in a Dry Colorado Garden" Sunset Magazine, Sunset Publishing Corp. Vol. 208 Issue: 4 (April 2002) pp. 92+

[18] Sobhi, M. "The Role of Sustainable Landscape Elements in Solving the Problem of Water in Residential Compounds" Master Thesis, Helwan University, Faculty of EngineeringMataria, Architectural department, Cairo, 2014

\section{الزيريسكيب كمدخل للحفاظ على الماء فى مشروعات تنسيق الموقع}

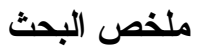

الماء مصدر نادر ومهم للحياة ويجب الحفاظ عليه بعد أن أصبح العالم بعانى من نقص المياه. وبالرغم من استهلاك مجال تتسيق

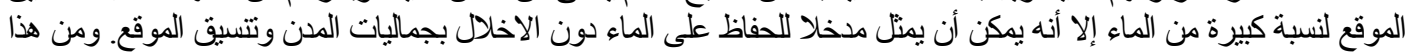

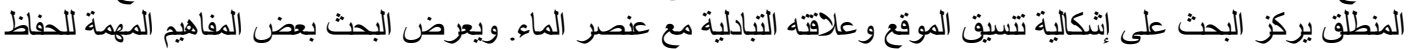

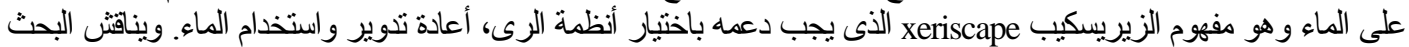

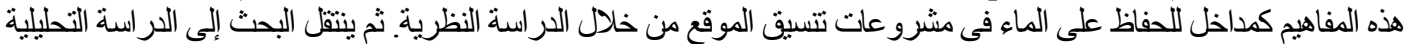

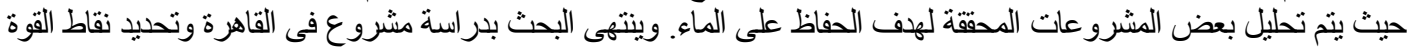

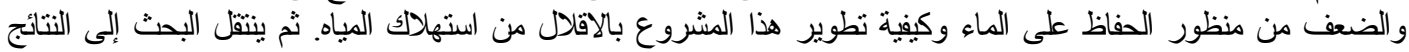
و التوصيات الخاصة بالبحث و التى توجه إلى تحقيق الهذف منه وهو الحفاظ على الماء خلال مشرو عات تلتسيق الموقع. 